\title{
Business
}

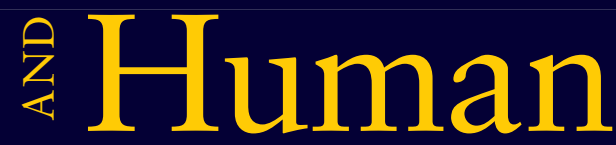

Rights

Journal

Special Issue: From Formalism to

Feminism: Gender, Business and Human Rights

Guest Editors: Nora Götzmann, Joanna Bourke Martignoni, Bonita Meyersfeld and Harpreet Kaur 


\section{Business and Human Rights Journal}

The Business and Human Rights Journal (BHRJ) provides an authoritative platform for scholarly debate on all issues concerning the intersection of business and human rights in an open, critical and interdisciplinary manner. It seeks to advance the academic discussion on business and human rights as well as promote concern for human rights in business practice.

$B H R J$ strives for the broadest possible scope, authorship and readership. Its scope encompasses interface of any type of business enterprise with human rights, environmental rights, labour rights and the collective rights of vulnerable groups. The Editors welcome theoretical, empirical and policy / reform-oriented perspectives and encourage submissions from academics and practitioners in all global regions and all relevant disciplines.

A dialogue beyond academia is fostered as peer-reviewed articles are published alongside shorter 'Developments in the Field' items that include policy, legal and regulatory developments, as well as case studies and insight pieces.

Business and Human Rights Journal is included on the Cambridge Core online platform and can be found at cambridge.org/core/journals/business-and-human-rights-journal

ISSN: 2057-0198

E-ISSN: 2057-0201

(C) Cambridge University Press 


\title{
Business and Human Rights Journal \\ Editorial Team
}

\author{
Editors-in-Chief
}

Surya Deva, Macquarie Law School, Macquarie University, Australia

Anita Ramasastry, University of Washington School of Law, USA

Michael Santoro, Santa Clara University, USA

Florian Wettstein, University of St Gallen, Switzerland

\section{Book Review Editors}

Nadia Bernaz, Wageningen University, the Netherlands

Samentha Goethals, SKEMA Business School, France

\section{Editorial Board}

Michael K Addo, University of Notre Dame

London Law Centre, UK

Denis G Arnold, University of North

Carolina at Charlotte, USA

Dan Banik, University of Oslo, Norway

Tim Bartley, Stockholm University, Sweden

Dorothee Baumann-Pauly, NYU Stern

School of Business, USA/University of

Geneva, Switzerland

Upendra Baxi, Warwick University, UK

David Bilchitz, University of Johannesburg, South Africa

Danny Bradlow, University of Pretoria, South Africa

Humberto Cantú Rivera, Universidad de Monterrey, Mexico

Barnali Choudhury, Osgoode Hall Law School, York University, Canada

Shane Darcy, National University of Ireland Galway, Ireland

Olivier De Schutter, University of Louvain, Belgium

Thomas Donaldson, Wharton School of the University of Pennsylvania, USA

Björn Fasterling, EDHEC Business School, France

Erika George, University of Utah, USA

Elisa Giuliani, University of Pisa, Italy

David Hess, Ross School of Business at the University of Michigan, USA

Nien-hê Hsieh, Harvard Business School, USA

Sarah Joseph, Griffith University, Australia

Markus Krajewski, Friedrich-Alexander-

Universität, Germany
Vivek Krishnamurthy, University of Ottawa, Canada

Genevieve LeBaron, Simon Fraser University, Canada

Jernej Letnar Cernič, New University, Slovenia

Jena Martin, West Virginia University, USA

Robert McCorquodale, University of Nottingham, UK

Ken McPhail, University of Manchester, UK

Peter Muchlinski, SOAS University of

London, UK

Justine Nolan, University of New South Wales, Australia

Claire Methven O'Brien, University of Dundee, UK

Ibironke Odumosu-Ayanu, University of Saskatchewan, Canada

Guido Palazzo, University of Lausanne, Switzerland

Kish Parella, Washington and Lee University, USA

Nicolás M Perrone, Universidad Andrés Bello, Chile

César Rodríguez-Garavito, New York University School of Law, USA

Marcelo Saguier, Universidad Nacional de San Martín (UNSAM), Argentina

Judith Schrempf-Stirling, University of Geneva, Switzerland

Sara Seck, Dalhousie University, Canada

Penelope Simons, University of Ottawa, Canada 
Vasanthi Srinivasan, Indian Institute of Management, Bangalore, India

Olena Uvarova, Yaroslav Mudryi National Law University, Ukraine

Tara Van Ho, University of Essex, $U K$
Sandra Waddock, Carroll School of Management, Boston College, USA

Patricia H Werhane, University of Virgina, USA Wanhong Zhang, Wuhan University School of Law, China

\section{Developments in the Field Panel}

Charles Abrahams, Abrahams Kiewitz, South Africa

Felogene Anumo, Thousand Currents, Africa Jelena Arapac, United Nations Working Group on the Use of Mercenaries

Caio Borges, Instituto Clima e Sociedade, Brazil

Flaviana Charles, Legal and Human Rights Centre, Tanzania

Han Dongfang, China Labour Bulletin, Hong Kong

Anthony Ewing, Teaching Business and Human Rights Forum, Columbia University, USA

Beata Faracik, Polish Institute for Human Rights and Business, Poland

Sara Hossain, Dr Kamal Hossain and Associates, Bangladesh

Mariëtte van Huijstee, Rathenau Instituut, the Netherlands

PillKyu Hwang, Gonggam Human Rights Law Foundation, Republic of Korea

Jonathan Kaufman, Advocates for Community Alternatives, USA

Harpreet Kaur, United Nations Development Programme

Juana Kweitel, Conectas Human Rights, Brazil

Rae Lindsay, Clifford Chance, $U K$

Richard Meeran, Leigh Day, UK

Anirudha Nagar, Accountability Counsel, India
Emmanuel Umpula Nkumba, Afrewatch, DRC

Ron Popper, Global Business Initiative on Human Rights, Switzerland

Michael Posner, NYU Stern Center for Business and Human Rights, USA

Paloma Muñoz Quick, BSR, USA

Gabriela Quijano, Business and Human Rights Consultant, UK

Miriam Saage-Maaß, European Center of Constitutional and Human Rights (ECCHR), Germany

Ruwan Subasinghe, International Transport Workers' Federation, UK

Salil Tripathi, Institute for Human Rights and Business, $U K$

Anneke Van Woudenberg, Rights and Accountability in Development (RAID), UK

Fernanda Venzon, Environmental Defender Law Center, USA

Paul Quayle Watchman, Glasgow University, $U K$

Joseph Wilde-Ramsing, SOMO (Centre for Research on Multinational Corporations), the Netherlands

Chima Williams, Environmental Rights Action/Friends of the Earth, Nigeria

Liang Xiaohui, China National Textile and Apparel Council, China

Miwa Yamada, Institute of Developing Economies, Japan

Vanessa Zimmerman, Pillar Two, Australia

\section{Blog and Media Editors}

Sandhya Drew, City University of London, UK

Rajiv Maher, Egade Business School, Mexico

\section{Social Media Editor}

Akiko Sato, Human Rights Now, Japan

\section{BHRJ Fellow}

Okwudili Onyenwee Onwurah, School of Law, City University of Hong Kong, Hong Kong 


\section{Business and Human Rights Journal}

\section{Table of Contents}

Special Issue: From Formalism to Feminism: Gender, Business and Human Rights

Guest Editors: Nora Götzmann, Joanna Bourke Martignoni, Bonita Meyersfeld and Harpreet Kaur

\section{EDITORIAL}

1 From Formalism to Feminism: Gender, Business and Human Rights

Nora Götzmann, Joanna Bourke Martignoni, Bonita Meyersfeld and Harpreet Kaur

\section{SCHOLARLY ARTICLES}

12 Enough of the 'Snake Oil': Applying a Business and Human Rights Lens to the Sexual and Reproductive Wellness Industry Clare Patton, Marisa McVey and Ciara Hackett

29 Overcoming Silencing Practices: Indigenous Women Defending Human Rights from Abuses Committed in Connection to Mega-Projects: A Case in Colombia Nancy R Tapias Torrado

45 Fast Fashion for 2030: Using the Pattern of the Sustainable Development Goals (SDGs) to Cut a More Gender-Just Fashion Sector

Ramona Vijeyarasa and Mark Liu

67 Informal Mining in Colombia: Gender-Based Challenges for the Implementation of the Business and Human Rights Agenda

Lina M Céspedes-Báez, Enrique Prieto-Ríos and Juan P Pontón-Serra

84 Women and the 'Business' of Human Rights: The Problem with Women's Empowerment Projects and the Need for Corporate Reform

Roseanne Russell

100 Reframing Corporate Subjectivity: Systemic Inequality and the Company at the Intersection of Race, Gender and Poverty

Charmika Samaradiwakera-Wijesundara

117 The United Nations Guiding Principles on Business and Human Rights, Women and Digital ID in Kenya: A Decolonial Perspective Grace Mutung'u

134 Reclaiming the Human Rights Foundations of the UN Standards of Conduct for Business on Tackling Discrimination against LGBTI People

Amanda Lyons and Cooper Christiancy 


\section{DEVELOPMENTS IN THE FIELD}

157 Selling Stereotypes: Reviewing the Impact of Business Advertisements on Gender Norms and Socialization

Bernadette Gutmann, Shreyasi Jha, Emer O'Doherty and Ranjavati Banerji

163 The Human Rights Implications of Not-for-Profit Surrogacy Organizations in Cross-Border Commercial Surrogacy: An Australian Case Study Yingyi Luo, Shelley Marshall and Denise Cuthbert

168 The Implications of the Adoption of a Model Sexual Harassment Policy Within the Flower Sector in Kenya

\section{Mary Kuira}

175 A Feminist Analysis of the Legal Mechanisms of Protection and Repair in the Context of the Brazilian Extractive Industry: The Doce River Case Juliana Bertholdi and Danielle Anne Pamplona

181 Private Military and Security Companies and Gendered Human Rights Challenges: Oversight or Blatant Disregard?

Sorcha MacLeod and Nelleke van Amstel 